\title{
Knowledge, attitudes and perceived barriers to emergency contraception among health staff in a tertiary hospital in Yaounde, Cameroon
}

\section{Jeanne Hortence Fouedjio ${ }^{1,2}$, Jovanny Tsuala Fouogue ${ }^{1 *}$ Florent Ymele Fouelifack $^{2,3,4}$, Valerie Ngankol Mout ${ }^{5}$, Loïc Dongmo Fouelifa ${ }^{6}$, Zacharie Sando ${ }^{5}$}

\footnotetext{
${ }^{1}$ Department of Obstetrics and Gynaecology, Faculty of Medicine and Biomedical Sciences, University of Yaoundé 1, Yaoundé, Cameroon

${ }^{2}$ Department of Obstetrics and Gynaecology, Yaoundé Central Hospital, Yaoundé, Cameroon

${ }^{3}$ Department of Obstetrics and Gynecology, Higher Institute of Medical Technology of Nkolondom, Yaoundé, Cameroon

${ }^{4}$ Research, Education and Health Development Group, Gares falaise, Dschang, Cameroon

${ }^{5}$ Department of morphological Sciences, Faculty of Medicine and Biomedical Sciences of the University of Yaoundé

1, Cameroon

${ }^{6}$ Faculty of Medicine, University of Lomé, Togo, School of Armies Health Services of Lomé, Togo.
}

Received: 17 October 2015

Accepted: 18 November 2015

*Correspondence:

Dr. Jovanny Tsuala Fouogue,

E-mail: fotsujo@outlook.com

Copyright: (C) the author(s), publisher and licensee Medip Academy. This is an open-access article distributed under the terms of the Creative Commons Attribution Non-Commercial License, which permits unrestricted non-commercial use, distribution, and reproduction in any medium, provided the original work is properly cited

\section{ABSTRACT}

Background: Unsafe abortion is a scourge worldwide. In Cameroon, modern contraceptive prevalence is $16 \%$, with unmet need of $25 \%$. Knowledge and attitudes of health staff toward emergency contraception (EC) are unknown. The aim of this study was to assess knowledge, attitudes of health staff towards EC and determine barriers they perceived to its popularization.

Methods: A descriptive cross-sectional study was carried out in a tertiary Hospital from April 1, to June 30, 2015 on a convenient sample of 150 health workers. All the staff present in the facility on the day of the survey was eligible. A pre-tested and anonymous questionnaire was distributed to 150 health staff. Data were analyzed using SPSS® software.

Results: The response rate was $78.7 \%$ (118/150). Mean age was $34.7 \pm 8.8$ years and $94.9 \%(112 / 118)$ of respondents were Christians. The mean number of children per respondent was $2.5 \pm 1.6$ and the mean duration of professional experience was $6.9 \pm 6.6$ years. Eighty nine $(75.4 \%)$ respondents were women and sixty $(50.8 \%)$ were nurses. Awareness was good (87.5\%), but knowledge was insufficient for $44.1 \%(52 / 118)$ and poor for $11.9 \%(14 / 118)$ of respondents. Attitudes towards EC were appropriate for 44.6\% (46/103) of respondents. Eighty percent of respondents were not satisfied with their knowledge and $90.4 \%$ requested training on EC. Perceived barriers were: promotion of precocious (82.9\% of respondents) and unprotected $(75.4 \%)$ sex, side effects $(70.6 \%)$, liability $(47.7 \%)$ and ethical/religious $(42.2 \%)$ principles.

Conclusions: Knowledge and attitudes of health staff towards EC was inadequate. Promotion of precocious and unprotected sex was the main perceived barrier to EC. Health staff needs training on EC.

Keywords: Emergency Contraception, Knowledge, Attitudes, Barriers, Health Staff, Cameroon. 


\section{INTRODUCTION}

Worldwide, despite contraception, 41\% (85 280000 ) of the 208000000 yearly registered pregnancies are unintended. As a result, the need for abortion is high but access to legal and safe abortion is very poor in resourcelimited countries. Nineteen million unsafe abortions occur worldwide each year resulting in 70000 deaths of women. ${ }^{1-4}$

In Cameroon, the overall contraceptive prevalence (modern methods) is 16\% and the unmet need for family planning methods is $17 \%$. Legislation on abortion is very restrictive. Terminations of pregnancies are therefore usually carried out by unskilled persons in inappropriate environment leading to severe complications including death. Emergency Contraception (EC) can therefore be a solution if it is widely used. Indeed, EC has been shown to reduce the number of unintended pregnancies and is promoted by the United Nations Population Fund, the World Health Organization, and the International Federation of Gynecology and Obstetrics. To the best of our knowledge there is no published data on the prevalence of EC in Cameroon; but it is certainly very low like that of "classical" contraception. The 2011 National Demographic and Health survey revealed that only $32.5 \%$ of women and $33.5 \%$ of men of reproductive age know the existence of emergency contraceptive pills. This is unacceptably low, but awareness and use of EC in the general population reflects the knowledge, prescription practices and attitudes of health staff towards EC. Knowledge and behaviour of health personnel towards EC have not yet been assessed in Cameroon. ${ }^{5-7}$

The term "Emergency Contraception" (EC) refers to a group of methods used to avoid pregnancy after unprotected sexual intercourse. EC is sometimes inappropriately referred to as "post-coïtal" and "morningafter" contraception. ${ }^{9}$

EC encompasses the following methods.

1. Copper intra-uterine device (IUD) which is effective up to seven days after intercourse.

2. Levonorgestrel (LNG) emergency contraception regimens that can be effective up to 5 days after intercourse (the single dose regimen $(1.5 \mathrm{mg}$ ) and the double dose levonorgestrel regimen $(0.75 \mathrm{mg} 12$ hours apart).

3. Ulipristal Acetate (UPA) which is effective up to 5 days after intercourse (single dose of 30 milligrams).

4. Mifepristone (at much lower doses than for induced abortion $10-60$ milligrams) that is effective up to 5 days after intercourse.

5. The Yuzpe's method (Combined oestrogenprogesterone pill) which is effective up to three days after the intercourse. ${ }^{10-12}$

Levonorgestrel is the only emergency contraceptive pill licensed in Cameroon, but it is not available over-thecounter.
The goal of this study was to determine the current knowledge and attitudes of health staff (nurses, medical doctors and laboratory staff/biologist) towards EC and to determine (perceived) barriers to its use.

\section{METHODS}

\section{Study design and participants}

We conducted a cross-sectional and descriptive study from April 1, 2015 to June 30, 2015 at the Yaounde Central Hospital $(\mathrm{YCH})$. The $\mathrm{YCH}$ is a tertiary and teaching Hospital that serves as referral health facility for Cameroun and other central Africa countries. The former paediatric department is currently entirely autonomous and independent from the management team of the YCH. All the health personnel present in the hospital on the day of the survey were eligible for the study.

\section{Data-collection procedure}

Data were collected on a structured pre-tested and precoded 36-item self-applied questionnaire. Health Staff who gave consent received a hard copy of the questionnaire. They were asked to deposit their answers at the secretariat of their unit where the main investigator then collected the filled out questionnaires. The questionnaire had four sections. The first section consisted of socio-demographic characteristics: age, sex, number of living children, department, qualification, marital status, religion and the number of years of professional experience. The three remaining sections retrieved information on knowledge, attitude and perceived barriers to EC. Questions in those sections were designed using a matrix of dimensions that is described in Table 1. Data were compiled on an excel sheet.

\section{Ethical requirements}

Prior to the survey, an ethical clearance was obtained from the Regional Committee for Ethics in Human Health Research $\left(\mathrm{N}^{\circ} \mathrm{CE} 001 / \mathrm{CRERSHC} / 2015\right)$. An authorization ( $\mathrm{N}^{\circ} 834$ L/MINSANTE/SG/DHCY/CM) was also obtained from the director of the $\mathrm{YCH}$. Informed consent and confidentiality were also ensured.

\section{Statistical analysis}

Our convenient sample size was 150 . We used Microsoft Excel ${ }^{\circledR}$ (version 2010) software for data entry. Statistical analysis was done using the Statistical Package for Social Sciences (SPSS) software programme (version 12.0, Chicago, IL, USA). For descriptive statistics, results were expressed in terms of proportions or percentages and means (standard deviation). The scoring system used to appreciate knowledge and attitudes is described in Table $2 .^{13}$ 
Table 1: Matrix of dimensions.

\begin{tabular}{|c|c|c|}
\hline Dimensions & Components & Variables \\
\hline \multirow{12}{*}{ Knowledge of EC } & $\mathrm{EC}$ & - $\quad$ Awareness of EC \\
\hline & \multirow{2}{*}{ Side effects of EC } & $\begin{array}{l}\text { - Knowledge of the absence of causal relationship between } \\
\text { EC and abortion }\end{array}$ \\
\hline & & $\begin{array}{l}\text { Knowledge of the main side effect of the Hormonal } \\
\text { emergency contraceptive pill }\end{array}$ \\
\hline & Prescription of EC & $\begin{array}{l}\text { - Knowledge of the fact that pregnancy test is not necessary } \\
\text { before prescribing EC }\end{array}$ \\
\hline & \multirow{5}{*}{ Methods of EC } & - $\quad$ Knowledge of the Yuzpe's Method \\
\hline & & - $\quad$ Knowledge of Levonorgestrel EC pill \\
\hline & & - $\quad$ Knowledge of Mifepristone EC pill \\
\hline & & - $\quad$ Knowledge of Ulipristal acetate EC pill \\
\hline & & - Knowledge of Intra Uterine Device as a method of EC \\
\hline & \multirow{3}{*}{ Efficacy of EC } & $\begin{array}{l}\text { - Knowledge of the delay of efficacy of the EC pill, after } \\
\text { sexual intercourse }\end{array}$ \\
\hline & & $\begin{array}{l}\text { Knowledge of the delay of efficacy of EC methods after } \\
\text { sexual intercourse }\end{array}$ \\
\hline & & - Knowledge of the mean percentage of efficacy of EC \\
\hline \multirow{9}{*}{ Attitudes towards EC } & \multirow{4}{*}{ Promotion of EC } & - $\quad$ Risk / benefit balance of EC \\
\hline & & - $\quad$ Systematic counselling on EC during routine consultations \\
\hline & & - Effect of EC on the prevalence of "classical" contraception \\
\hline & & - $\quad$ Necessity to intensify/start sensitization on EC \\
\hline & \multirow{3}{*}{ Training on EC } & - Having done a further training on EC \\
\hline & & - $\quad$ Satisfaction with their knowledge of EC \\
\hline & & - Willingness to follow a specific training on EC \\
\hline & \multirow[b]{2}{*}{ Prescription of EC } & - $\quad$ Ever prescribed EC \\
\hline & & $\begin{array}{l}\text { - Systematic referral of patients to obstetrician/Gynaecologist } \\
\text { for EC }\end{array}$ \\
\hline \multirow{7}{*}{ Barriers to EC } & \multirow{7}{*}{$\begin{array}{l}\text { Perceived barriers to } \\
\text { EC }\end{array}$} & - $\quad$ Promotion of precocious sex \\
\hline & & Promotion of unprotected sex \\
\hline & & - $\quad$ Ethical/religious considerations \\
\hline & & - $\quad$ Medicol-legal considerations \\
\hline & & - Lack of professional experience/ self-confidence \\
\hline & & - $\quad$ Fear of side/malformative effects \\
\hline & & - $\quad$ Poor access/availability of EC \\
\hline
\end{tabular}

EC: Emergency Contraception

\section{RESULTS}

\section{Participation rate}

Out of the 150 health workers who accepted to participate, 118 returned the questionnaire, giving a response rate of $78.7 \%$.

\section{Socio-demographic characteristics of respondents}

Table 3 shows socio-demographic data of the respondents. The mean age of respondents was $34.7 \pm 8.8$ years (range 19 - 54). The mean number of living children per respondent was $2.5 \pm 1.6$ (range $1-7$ ). The mean duration of professional experience was $6.9 \pm 6.6$ years (range 1 - 28). $112(94.9 \%)$ respondents were Christians, $52(44.1 \%)$ were formally married and 89 $(75.4 \%)$ were female. Sixty $(50.8 \%)$ respondents were nurses and $38(32.2 \%)$ were working in the department of obstetrics/Gynecology.

\section{Knowledge of EC}

Appreciation of Knowledge of respondents towards EC is shown in table 4. Globally, 44.1\% (52 out of 118) of respondents had insufficient knowledge and $11.9 \%$ (14 out of 118) had poor knowledge of EC. 
Table 2: Scoring system for appreciation of knowledge and attitudes.

\begin{tabular}{|lllll|}
$\begin{array}{l}\text { Score (proportion } \\
\text { of correct } \\
\text { answers) }\end{array}$ & $\begin{array}{l}\text { No of correct } \\
\text { answers in } \\
\text { "Knowledge" }\end{array}$ & $\begin{array}{l}\text { Appreciation of } \\
\text { "Knowledge" }\end{array}$ & $\begin{array}{l}\text { Number of correct } \\
\text { answers in "attitudes" }\end{array}$ & $\begin{array}{l}\text { Appreciation of } \\
\text { "attitudes" }\end{array}$ \\
\hline $0-25 \%$ & 0 to 3 & Poor & 0 to 2 & Poor \\
\hline $26-49 \%$ & 4 to 6 & Insufficient & 3 to 5 & Inadequate \\
\hline $50-70 \%$ & 7 to 9 & Average /Quite good & 6 to 7 & Acceptable /Quite good \\
\hline $71-100 \%$ & 10 to 13 & Good & 8 to 9 & Good \\
\hline
\end{tabular}

Specifically $87.5 \%$ of respondents were aware of EC and $90.1 \%$ of them know that emergency pill was a mean of EC. $22 \%$ and $12.2 \%$ of respondents knew that EC was possible with copper Intra-Uterine Device (IUD) and Ulipristal acetate respectively. $64 \%$ of respondents know that mifepristone could be used as EC and $39.3 \%$ of respondents knew that combine oral contraceptive (Yuzpe's method) could be used for EC. $46 \%$ of respondents thought that EC was a method of abortion. For $45.5 \%$ of respondents EC pill was effective only within the 24 hours after sexual intercourse and for $50 \%$ of respondents a pregnancy test must be done prior to EC. For $76.1 \%$ of respondents menstrual disturbance was the commonest side effect of EC pill. The mean percentage of efficacy of EC was not known by $69.8 \%$ of respondents.

\section{Attitude towards EC}

Appreciation of attitudes of respondents towards EC is shown in Table 4. Globally, attitude towards EC was appropriate for $44.6 \%$ (46 out of 103) of respondents.

Specifically, $53.9 \%$ of respondents had already prescribed EC and $65.2 \%$ thought that its benefits don't outweigh the risks. $80.5 \%$ of respondents were not satisfied with their level of knowledge on EC and $90.4 \%$ of them wished to be trained on EC. Only $56.3 \%$ of participants answered that EC should be promoted.

\section{Perceived barriers to EC}

These barriers are shown in Table 5. For $82.9 \%$ of respondents EC promotes unprotected sex and for $75.4 \%$ of them EC promotes precocious sex. For $70.6 \%$ of respondents fear of side effects was an obstacle to EC.

\section{DISCUSSION}

\section{Awareness of EC}

Awareness of EC was high $(87.5 \%)$ in our sample but more than half of our respondents had inappropriate (either poor $(11.9 \%)$ ) or insufficient $(44.1 \%)$ ) level of knowledge of EC. This is similar to the findings by: Gichangi et al among nurses in Kenya, ${ }^{14}$ by MorhasonBello et al among junior medical doctors in Nigeria, ${ }^{15}$ by Reed et al among nurses and physicians in the USA, ${ }^{16}$ by Abdulghani et al among health staff in Pakistan, by Aksu et al in Turkey and by Oriji et al among medical doctors in Nigeria. ${ }^{17-19}$ On the contrary, the following authors found an adequate level of Knowledge of EC: NajafiSharjabad et al, among health staff in Iran , Weisberg et al among General Practitioners in Great Britain and Nivedita et al among nurses in India. ${ }^{20,21}$ Awareness of EC in our sample was certainly high because respondents were working in a referral and teaching Hospital in the capital of the country where information technologies favour learning and self-training. Moreover, all our respondents had at least one living child. For their own family planning they may have heard about EC.

\section{Knowledge of EC}

Concerning knowledge of EC, the overall score of our sample was poor because it was made up of $50.8 \%$ of nursing personnel and only $28 \%$ of physicians who are supposedly more knowledgeable of EC. Moreover, respondents working in emergencies and in the unit of Obstetrics and Gynaecology accounted for only $43.2 \%$ of our sample while those working in other units are less likely to deal regularly with patients requiring EC. Overall knowledge score was low despite the fact that young health workers (less than five years of experience) who are supposed to have better mastery of concepts taught in professional schools accounted for more than half of our sample $(51.7 \%)$. This indicates that teaching curricula in our professional schools may not emphasize on EC. Health staff has considerable influence of women's contraceptive behavior. ${ }^{11,20,21}$ Thus, our finding of weak knowledge of EC correlates with the poor national contraceptive prevalence and with poor knowledge of EC among university students. ${ }^{6,23}$ A last, another possible explanation of inadequate knowledge despite high awareness of EC may be the fact that the majority of our respondents were Christians (94.9\%). Christian Religions are strongly opposed to EC and religion has been shown to influence knowledge and prescription of EC by health personnel. ${ }^{15,24}$ 
Table 3: Socio-demographic characteristics of respondents.

\begin{tabular}{|c|c|c|c|}
\hline Characteristics & & Frequency & Proportion (\%) \\
\hline \multirow{5}{*}{ Age (years) } & $18-30$ & 46 & 39,0 \\
\hline & $31-45$ & 57 & 48,3 \\
\hline & $46-60$ & 15 & 12,7 \\
\hline & $\geq 61$ & 0 & 0,0 \\
\hline & Total & 118 & 100,0 \\
\hline \multirow{3}{*}{ Sex } & Female & 89 & 75,4 \\
\hline & Male & 29 & 24,6 \\
\hline & Total & 118 & 100,0 \\
\hline \multirow{5}{*}{ Marital status } & single & 54 & 45,8 \\
\hline & Married & 52 & 44,1 \\
\hline & NA & 5 & 4,2 \\
\hline & Widow(er) & 7 & 5,9 \\
\hline & Total & 118 & 100,0 \\
\hline \multirow{5}{*}{ Number of living Children } & 0 & 0 & 0,0 \\
\hline & $1-3$ & 88 & 74,6 \\
\hline & $4-5$ & 24 & 20,3 \\
\hline & $\geq 6$ & 6 & 5,1 \\
\hline & Total & 118 & 100,0 \\
\hline \multirow{6}{*}{ Qualification } & Biomedical staff & 18 & 15,3 \\
\hline & Nurse & 60 & 50,8 \\
\hline & GP & 16 & 13,6 \\
\hline & Resident doctor & 17 & 14,4 \\
\hline & NA & 7 & 5,9 \\
\hline & Total & 118 & 100,0 \\
\hline \multirow{4}{*}{ Professional experience (years) } & $0-5$ & 61 & 51,7 \\
\hline & $6-15$ & 47 & 39,8 \\
\hline & $\geq 16$ & 10 & 8,5 \\
\hline & Total & 118 & 100,0 \\
\hline \multirow{7}{*}{ Unit/Department } & Paraclinical Units & 27 & 22,9 \\
\hline & Surgery & 13 & 11,0 \\
\hline & Obstetrics/Gynecology & 38 & 32,2 \\
\hline & Internal Medicine & 25 & 21,2 \\
\hline & NA & 2 & 1,7 \\
\hline & Emergencies & 13 & 11,0 \\
\hline & Total & 118 & 100,0 \\
\hline \multirow{4}{*}{ Religion } & Christianism & 112 & 94,9 \\
\hline & Islam & 2 & 1,7 \\
\hline & NA & 4 & 3,4 \\
\hline & Total & 118 & 100,0 \\
\hline
\end{tabular}

NA: Not available GP: General Practitioner

9 out of 10 respondents knew about EC pill which is the most popular EC method worldwide. ${ }^{11}$ Though IUD is the most effective method of EC, only $22 \%$ of respondents knew that it could be used for EC. ${ }^{11}$ Use of IUD as a method of EC is a very specific knowledge that could be peculiar to physicians ( $28 \%$ of our sample) and/or health staff working in units of Obstetrics and Gynaecology (32.2\% of our respondents). A study among medical doctors in Nigeria found that IUD was the commonest method they used for EC. ${ }^{19}$ Ulipristal acetate which is not licensed in Cameroon was recognised as a method of EC by only $12 \%$ or our respondents. Mifepristone is not licensed in Cameroon because it is still considered as an abortifacient but $64 \%$ percent of respondent identified it as a method of EC. This is in accordance with the proportion $(46 \%)$ of respondents who considered EC as a method of early abortion. Gichangi et al had similar findings (49\%) among nurses in Kenya. ${ }^{14}$ In fact low doses of Mifepristone are licensed for EC in a small number of countries like China, Russia, Vietnam and Armenia. ${ }^{11}$ Almost half $(45.5 \%)$ of our respondents did not known that EC pill can be effective more than 24 
hours after intercourse. This may be due the popular but inappropriate name "morning-after pill" which was even used during the 2011 national Demographic and Health Survey. ${ }^{6,9}$ Nivedita et al and Gichangi et al had similar findings among nurses in India and in Kenya respectively. ${ }^{14,22}$ Menstrual disturbance was (wrongly) identified by $76.1 \%$ of respondents as the commonest side effect of EC pills instead of nausea and vomiting that may reduce efficacy. ${ }^{11}$

Table 4: Knowledge and attitudes of respondents towards emergency contraception.

\begin{tabular}{|llll|}
\hline \multirow{3}{*}{ Appreciation } & & Frequency & Proportion (\%) \\
\hline \multirow{3}{*}{ Knowledge } & Poor & 14 & 11,9 \\
\cline { 2 - 4 } & Insufficient & 52 & 44,1 \\
\cline { 2 - 4 } & Average / Quite good & 48 & 40,7 \\
\cline { 2 - 4 } & Good & 4 & 3,4 \\
\hline \multirow{3}{*}{ Attitudes } & Potal & $\mathbf{1 1 8}$ & 7,8 \\
\hline & Inadequate & 8 & 47,6 \\
\cline { 2 - 4 } & Acceptable / Quite good & 49 & 25,2 \\
\cline { 2 - 4 } & Good & 26 & 19,4 \\
\cline { 2 - 4 } & Total & $\mathbf{1 0 0 , 0}$ \\
\hline
\end{tabular}

\section{Attitudes towards EC}

Half $(44.6 \%)$ of our participants had adequate attitude toward EC and half $(53.9 \%)$ of them had already prescribed it. This proportion seems high for a resourcelimited country like Cameroon but our survey was carried out in a tertiary and teaching hospital in the city capital. Nivedita et al (51.4\% of nurses had good attitudes) and Najafi-Sharjabad et al $(50 \%$ of health staff had good attitudes) had similar findings in India and Iran respectively. $^{20,21}$ Apart from that, $75.4 \%$ of our respondents were women and $44.1 \%$ were married.

Gender (female health workers have better attitudes than males) and marital status have impact on knowledge and behaviour of health workers. ${ }^{15,21} 8$ out of 10 respondents were not satisfied with their knowledge of EC and 9 out of 10 wished to receive specific training in EC. Asku et al and Nivedita et al had similar findings. ${ }^{18,22}$ This is expresses the need in further training of health staff on EC for the country where family planning is a strategic axis for reduction of maternal mortality. It has been shown that health personnel who had been trained on EC were more likely to prescribe and promote it. ${ }^{18}$ Only $56.3 \%$ of our respondents were favourable to promotion of EC. Gichangi et al had a similar proportion in Kenya $(53 \%) .{ }^{14}$ Again, the mean number of children per respondent $(2.5 \pm 1.6)$ and the huge proportion of Christians (94.9\%) in our sample may be an explanation.

\section{Perceived barriers to EC}

For most of our respondents, the main barriers to EC was the fact that it promotes precocious sexual activity among adolescents $(82.9 \%)$ and unprotected sex $(75.4 \%)$ in the era of HIV/AIDS (Human Immunodeficiency Virus/Acquired Immuno-Deficiency Syndrome). In a series among family physicians in Pakistan, Abdulghani et al found that $31 \%$ thought that EC was not wide-spread because it "increases promiscuity". ${ }^{17}$ In USA Miller et al found that nurses commonly expressed opinions that adolescents who need EC are irresponsible and that EC should only be used after an assault. ${ }^{11,25}$ Lack of experience in prescribing, was perceived as a barrier to EC by $56.1 \%$ of respondents and $47.7 \%$ thought that liability was also a barrier. Given that $46 \%$ of respondents consider EC as a method abortion which is still illegal in Cameroon it is understandable that almost the same percentage was concerned with liability. ${ }^{7}$ Abdulghani et al found similar figures. ${ }^{17}$ Ethical/religious principles were barriers to EC for $42.2 \%$ of our respondents. These finding appears like the consequence of the high proportion of Christians in our sample $(94.9 \%)$. In another setting were a majority of respondents were practicing believers, findings were similar. ${ }^{17}$ Another remarkable finding is that $31.8 \%$ of respondent estimated that $\mathrm{EC}$ was neither available nor accessible in the country. In fact Ulipristal acetate and Mifepristone are not licensed in Cameroon. Though Levonorgestrel is marketed over-the-counter, it is not available, accessible and affordable all over the country.

\section{Impact of the study}

To the best of our knowledge, this study is probably the first to assess knowledge and attitudes of health staff towards EC in Cameroon. It has revealed important deficiencies in knowledge and attitudes towards EC among health staff. It has yielded a glance of the barriers to EC as perceived by health staff. If our results are confirmed, specific training of health staff on EC will be necessary to ensure it effectiveness in the community. It has also thrown more light on this subset of contraception. 
Table 5: Perceived barriers to emergency contraception

\begin{tabular}{|lll|}
\hline Perceived barriers to EC & $\begin{array}{l}\text { Frequency / total number of } \\
\text { responses }\end{array}$ & \begin{tabular}{c} 
Proportion (\%) \\
\hline EC promotes unprotected sex
\end{tabular} \\
\hline EC promotes of precocious sex & $87 / 117$ & 75.9 \\
\hline Fear of side effects and/or teratogenicity of EC & $77 / 114$ & 70.6 \\
\hline Lack of experience in prescribing EC & $64 / 114$ & 56.1 \\
\hline Liability of the prescriber & $53 / 111$ & 47.7 \\
\hline EC is wrong for ethical/religious reasons & $49 / 116$ & 42.2 \\
\hline EC is neither available nor accessible & $35 / 110$ & 31.8 \\
\hline
\end{tabular}

EC: Emergency Contraception

\section{Limitations and perspectives}

The main limitation of our study is that all categories of health staff were included but the relatively small sample size that didn't permit subclass analysis. Another limitation is that no similar study conducted in Cameroon was found for comparison. Our sample was made up of $94.9 \%$ of Christians and thus failed to give an insight of the situation among health staff from other religions. Our study was limited to one health facility and it may not be generalized.

Further research may be carried out on a larger scale among each category of health personnel in both referral and primary health care.

\section{CONCLUSIONS}

This survey revealed that knowledge and attitudes of EC were inadequate among health staff in a tertiary and teaching Hospital in Cameroon. The main barriers to EC perceived by respondents were socio-cultural. Most of the participants requested further training in order to overcome those barriers in order to fully implement EC in community.

\section{ACKNOWLEDGEMENTS}

Authors express their gratitude to the direction of the $\mathrm{YCH}$ for the permission to conduct the research in their facility. They also thank all participants for their contribution.

Funding: No funding sources

Conflict of interest: None declared

Ethical approval: The study was approved by the Institutional Ethics Committee

\section{REFERENCES}

1. Singh S, Sedgh G, Hussain R. Unintended pregnancy: Worldwide levels, trends, and outcomes. Stud Fam Plann. 2010;41(4):241-50.

2. Grimes DA. Unsafe abortion: the silent scourge. British Medical Bulletin. 2003;67:99-113.
3. Grimes DA, Benson J, Singh S. Unsafe abortion: the preventable pandemic. Lancet. 2006;368(9550):1908-19.

4. Leke RJI, Nana NP (2012). Abortions in Low Resource Countries, Basic Gynecology - Some Related Issues, Prof. Atef Darwish (Ed.), ISBN: 978-953-51-0166-6, InTech, Available from: http://www.intechopen.com/books/basicgynecology-some-related-issues/abortions-inlow-resource-countriescase-study-of-cameroon.

5. International Consortium for Emergency Contraception: EC Status and Availability Database. [Accessed Oct 1, 2012].http://www.cecinfo.org/index.php

6. National Institute of Statistics - Cameroon. Demographic, Health and Multiple Indicators Cluster Survey 2011. Yaounde: Institut National de Statistique; 2012. Available on: http://www.statistics-

cameroon.org/manager.php?id=6.

7. Republic of Cameroon. Official gazette of the republic of Cameroon $\mathrm{N}^{\circ}$ 67/LF/1. 12 June s1967. Yaoundé. Cameroon.

8. Nana PN, Fomulu JN, Mbu RE, Ako SN, Leke RJI. A four-year retrospective review of postabortal surgical complications at the central maternity Yaounde, Cameroon. Clinics in Mother and Child Health. 2005;2(2):359-63.

9. Van Look PF, von Hertzen H. Emergency contraception.Br Med Bull. 1993;49(1):158-70.

10. Dunn S, Guilbert E. Society of Obstetricians and Gynaecologists of Canada. Emergency contraception. J Obstet Gynaecol Can. 2012;34(9):870-8.

11. Koyama A, Hagopian L, Linden J. Emerging Options for Emergency Contraception. Clin Med Insights Reprod Health. 2013;7:23-35.

12. Guida M, Marra ML, Palatucci V, Pascale R, Visconti F, Zullo F. Emergency Contraception: An Updated Review. Transl Med UniSa. 2011; 1: 271-294.

13. Essi MJ, Njoya O. L'enquête CAP en recherche médicale. Health Sci Dis. 2013; 14(2):1-3.

14. Gichangi PB, Karanja JG, Kigondu CS, Fonck K, Temmerman M. Knowledge, attitudes, and practices regarding emergency contraception among nurses and nursing students in two 
hospitals in Nairobi, Kenya. Contraception. 1999; 59(4):253-6.

15. Morhason-Bello IO, Adedokun BO, Mumuni TO. Knowledge and use of emergency contraception by medical doctors on internship in a tertiary healthcare facility in Nigeria. Niger J Clin Pract. 2014; 17(4):431-5.

16. Reed JL, Vaughn LM, Pomerantz WJ. Attitudes and knowledge regarding emergency contraception among emergency department adolescents and providers. Pediatr Emerg Care. 2012; 28(8):775-9.

17. Abdulghani HM, Karim SI, Irfan F. Emergency Contraception: Knowledge and Attitudes of Family Physicians of a Teaching Hospital, Karachi, Pakistan. J Health Popul Nutr. 2009;27(3):339-44.

18. Aksu H, Kucuk M, Karaoz B, Oğurlu N. Knowledge and attitudes of health care providers working in primary health care units concerning emergency contraception. Gynecol Obstet Invest. 2010;70(3):179-85.

19. Oriji VK, Omietimi JE. Knowledge, attitude, and practice of emergency contraception among medical doctors in Port Harcourt. Niger J Clin Pract. 2011;14:428-31.

20. Najafi-Sharjabad F, Hajivandi A, Rayani M. Glob J Health Sci. 2013; 6(1):52-60. Knowledge, attitude, and practice about Emergency Contraception among health staff in Bushehr state, south of Iran.
21. Weisberg E, Fraser IS, Carrick SE, Wilde FM. General practitioner knowledge, attitudes and practices in New South Wales. Med J Aust. Emergency contraception; 1995;162(3):136-8.

22. Nivedita K, Shanthini NF. Knowledge, Attitude and Practice of Emergency Contraception on Nursing Personnel. J Clin Diagn Res. 2014;8(9):OC20-OC22.

23. Kongnyuy EJ, Ngassa P, Fomulu N, Wiysonge CS, Kouam L, Doh AS. A survey of knowledge, attitudes and practice of emergency contraception among university students in Cameroon. BMC Emergency Medicine. 2007 $7: 7$.

24. Guzman V, Seibert U, Staab S. Democracy in the country but not in the home? Religion, politics and women's rights in Chile. Third World Q. 2010;31(6):971-88.

25. Miller MK, Plantz DM, Dowd DM et al. Pediatric emergency health care providers' knowledge, attitudes, and experiences regarding emergency contraception. Acad Emerg Med. 2011;18(6):605-12.

Cite this article as: Fouedjio JH, Fouogue TH, Fouelifack FY, Mout VN, Fouelifa DL, Sando Z. Knowledge, attitudes and perceived barriers to emergency contraception among health staff in a tertiary Hospital in Yaounde, Cameroon. Int J Reprod Contracept Obstet Gynecol 2015;4:2014-21. 